$\nabla$ Artikkeli

\title{
Viestinnän ammattilaiset promootioyhteiskunnassa: aktivisteja ja ajatusjohtajia
}

\begin{abstract}
Viestintätoimistojen, konsulttien ja muiden PR-ammattilaisten käyttö on lisääntynyt Suomessa 2000-luvulla ja levinnyt entistä enemmän yrityselämästä julkiselle sektorille ja järjestöihin. Tässä artikkelissa kuvaamme tämän promootioyhteiskunnan keskeisen ammattikunnan kasvua ja työkäytäntöjä: miten ja millä keinoilla viestinnän ammattilaiset pyrkivät vaikuttamaan julkisuuteen? Tulkitsemme ammattikunnan nousua osana yhteiskunnan laajempaa muutosta ja pohdimme myös viestinnän konsultoitiin liittyviä kysymyksiä journalismin ohittamisesta, konsultoinnin läpinäkyvyydestä sekä rahan vallasta julkisuuden hallinnassa ja lobbauksessa. Artikkeli perustuu vuonna 2013 tehtyihin viestintäammattilaisten haastatteluihin.
\end{abstract}

AVAINSANAT: Organisaatioviestintä, PR, promootiokulttuuri, lobbaus, viestintäkonsultit

$\mathrm{P}$ romootiokulttuuri on käsite, jota on käytetty kuvaamaan nyky-yhteiskuntien luonnetta. Andrew Wernick (1991) esitti ensimmäisenä, että kulttuurimme on yhä enemmän kyllästetty promootiolla: markkinoinnilla, mainonnalla, suhdetoiminnalla eli PR:Ilä ja muulla ammattimaisella viestinnällä. Viime aikoina promootiokulttuurin käsitteen alla on tutkittu esimerkiksi brändäystä, kampanjointia ja poliittista markkinointia sekä muotien tai kuuluisuuksien luomista (McAllister \& West 2013; Davis 2013). Promootiosta voi myös puhua omana teollisuuden alanaan, jonka merkitys ja myös liikevaihto on kasvanut (Davis 2013, 2). Yhdysvalloissa arveltiin olevan vuonna 2008623000 promootion ammattilaista. Isossa-Britanniassa työskenteli vuonna 2011 markkinoinnin, mainonnan ja PR:n ammattilaisina arviolta 432000 ihmistä. (Davis 2013, 2.)

Promootiokulttuurin olennaisia osia ovat organisaatioiden viestintä ja PR, joilla organisaatiot ja instituutiot hoitavat suhteitaan yhteiskuntaan ja julkisuuteen. Organisaatiot pyrkivät muokkaamaan ja hallitsemaan julkista imagoaan ja organisaatiosta liikkuvaa informaatiota omien etujensa mukaisesti (Cottle 2004, 3). Heath $(2001,2)$ näkee tässä viestinnässä kaksi puolta. Yhtäältä viestintä auttaa organisaatioita edistämään ja suojelemaan imagoaan tai mainettaan ja tuottaa kasvaneita markkinaosuuk- 
sia, tuottoja, lahjoituksia tai rahoitusta tai toivottuja lakimuutoksia. Toisaalta viestintä pyrkii minimoimaan konflikteja ja niiden aiheuttamia kustannuksia. Se harmonisoi suhteita kumppaneihin ja sidosryhmiin ja luo hyvää tahtoa, joka tuo onnistuessaan rahassa mitattavia hyötyjä.

Eri instituutioiden viestintästrategioita on tutkittu jo pitkään kansainvälisesti (ks. hyvä yhteenveto Cottle 2003). Kriittinen tutkimus on selvitellyt sitä, kuinka erilaiset instituutiot ja eliittiryhmät pyrkivät vaikuttamaan politiikkaan ja julkisuuteen ja käyttämään niitä hyväkseen (Davis 2007, 55-73). Samalla on nostettu esiin erilaisia viestinnän strategioita. Usein viestinnän tavoitteena on lähinnä rutiiniesiintymisten hallinta sekä julkisuuden rajoittaminen (Davis 2004, 39). Esimerkiksi vaikeista asioista voidaan tiedottaa niin, etteivät ne nouse julkisuuden keskiöön ja julkisuuden huomio voidaan suunnata lanseeraamalla tiettyjä teemoja voimakkaasti. Journalisteihin voidaan luoda hyvät suhteet tai heitä voidaan estää pääsemästä tietyn organisaation edustajien puheille.

Yritykset ovat perinteisesti olleet ahkerimpia viestijöitä, mutta myös monenlaiset muut julkiset instituutiot ja järjestöt käyttävät viestintää ja PR:ää edistääkseen tavoitteitaan. Tutkimusta on tehty erityisesti puolueiden ja armeijan mediastrategioista (Franklin 1994; Scammel 1995; Schlesinger ym. 2001). Myös poliittisen markkinoinnin tutkimuksesta on tullut oma kiinnostava alueensa (Lilleker \& Lees-Marsment 2005; Lees-Marshment 2009). Monikanavaisessa ja fragmentoituneessa mediaympäristössä poliitikkojen on entistä vaikeampi kontrolloida vahingollista informaatiota ja kuvastoa (Hayden 2002; McNair 2000, 2006). Politiikassa myös puolueet ovat heikentyneet ja poliittisten keulakuvien ja johtajien merkitys on entistä ratkaisevampi (Karvonen 2010; McAllister 2007; Stanyer \& Wring 2004) ja poliitikot suunnittelevat julkiset esiintymistyylinsä tarkkaan (Corner 2003; Pels 2003; Van Santen \& Van Zoonen 2009). Samaan aikaan on ilmaantunut uusia järjestöjä ja liikkeitä (Moran 2008, 76), joille julkisuudesta on tullut tärkeä vaikutuskanava (Anderson 1993, 54-66; Davis 2002, 120-121).

Organisaatioiden viestintään kuuluu myös vaikuttajaviestintä tai lobbaaminen, jolla pyritään vaikuttamaan ennen kaikkea poliittisiin päätöksentekijöihin. Lobbaaminen on osa viestinnän ammattilaisten tarjoamaa tuotepalettia: asiakkaille tarjotaan palveluja, joilla voidaan tapauksesta riippuen vaikuttaa sekä julkisuuteen että päättäjiin (Allern 2011; Ihlen \& Berntzen 2007; Davis 2002; Naurin 2007).

Suomessa organisaatioiden viestinnän, PR:n ja vaikuttajaviestinnän merkitys on kasvanut seuraten aikaisempaa kehitystä muissa Länsi-Euroopan maissa ja Yhdysvalloissa. Monien yhteiskunnan instituutioiden viestintä on entistä ammatillisempaa ja huolellisemmin suunniteltua ja keinot ovat monipuolistuneet. Ammattimainen viestintä on ollut pitkään arkipäivää yrityksissä, mutta 1990-luvulta lähtien se on levinnyt yhä vahvemmin myös politiikkaan, julkiselle sektorille ja kansalaisjärjestöihin. Ministeriöt ja valtion erilaiset instituutiot sekä kansalaisjärjestöt, etu- ja painostusryhmät rakentavat määrätietoisesti viestintä- ja mediastrategioita ja käyttävät siihen ulkopuolisia palveluja. Esimerkiksi poliittiset puolueet käyttävät entistä enemmän viestinnän ammattilaisia ja konsultteja kampanjoidensa suunnittelussa (Herkman 2011, 110-114).

Kehitys näkyy alan ammattilaisten määrän kasvuna. Suomessa yritys- ja yhteisöviestinnän ammattilaisten ProCom-yhdistyksen jäsenmäärä kasvoi vuodesta 2007 vuoteen 
2012 noin 400 jäsenellä. Vuoden 2012 lopussa jäseniä oli noin kaksituhatta. Akavalaisen viestinnän asiantuntijoiden ammattiliiton Viestin jäsenmäärä on kasvanut viime vuosina vuosittain yhdeksän prosentin vauhtia ja jäseniä on noin 1400 . Yleinen trendi on, että yhä useammin PR:n ja viestinnän ammattilaiset työskentelevät siihen erikoistuneissa yrityksissä tai itsenäisinä konsultteina.

Viestinnän ammattilaisten tehtävänä on vaikuttaa julkisuuteen ja poliittiseen päätöksentekoon, ja siksi heidän työnsä on myös yhteiskunnallisesti kiinnostavaa ja merkittävää. Suomessa heitä on kuitenkin tutkittu melko vähän. Julkisuusstrategioita on käsitelty enimmäkseen käytäntöön keskittyvässä kirjallisuudessa (esim. Aula \& Heinonen 2011; Heinonen 2006) tai alan ammattilaisten opaskirjoissa (esim. Hurmerinta \& Pietilä 2008, Korpiola 2011). Päättäjien suhdetta mediaan on selvitetty haastattelututkimuksilla, joissa on käynyt ilmi, että suomalaiset yhteiskunnalliset vaikuttajat miettivät tarkkaan, miten ja milloin julkisuuteen menevät (Kantola 2002) ja myös kilpailevat siitä, kenen edustama näkökulma yltää journalismissa vallitsevaksi kannaksi (Kunelius, Noppari \& Reunanen 2009, 313). Aiempi tutkimus antaa myös olettaa, että julkisuus on tullut Suomessa aiempaa arvaamattomaksi ja päättäjät ovat joutuneet entistä enemmän hiomaan viestintästrategioitaan (Kantola 2011; Kantola \& Vesa 2013). Lobbaustutkimuksessa on selvitelty erilaisia lobbauksen malleja (Jaatinen 1999; 2000; 2003), poliitikkojen suhtautumista lobbaukseen (Ahonen \& Hanska 2010) sekä verkkoa lobbauksen välineenä (Gullman 2006).

Tässä artikkelissa selvitämme viestinnän ja PR:n ammattikunnan työkäytäntöjä: miten viestinnän ammattilaiset pyrkivät vaikuttamaan julkisuuteen ja poliittiseen päätöksentekoon? Samalla pohdimme mistä ammattikunnan kasvu Suomessa johtuu. Aineistoina ovat 15 viestinnän ammattilaisen teemahaastattelut, joita tulkitsemme laadullisella sisällönanalyysillä.

\section{Viestinnän ammattilaisten kenttä}

Mitä viestinnän ammattilaiset sanovat työstään: mitä he tekevät ja miten he näkevät oman ammattikuntansa yhteiskunnallisen merkityksen? Haastattelimme vuoden 2013 kesän ja kevään aikana 15 viestinnän ammattilaista ja konsulttia, jotka suunnittelevat ja toteuttavat organisaatioiden viestintää keskittyen medioihin tai yhteiskunnalliseen vaikuttajaviestintäään.

Valitsimme haastateltavat niin, että he edustavat suomalaista viestintätoimistojen ja ammattilaisten kenttää. Viestintätoimistot muodostavat osan kasvavaa markkinointiviestinnän toimialaa, jonka kokonaismarkkinat olivat vuonna 2012 noin 516 miljoonaa euroa - kasvua oli edelliseen vuoteen verrattuna 4,2 prosenttia. Suomessa Markkinointiviestinnän Toimistojen Liitto (MTL) jakaa markkinointiviestinnän yritykset digi-, mainos-, media-, tapahtuma- ja viestintätoimistoiksi.

Alalle on tyypillistä jakautuminen suuriin perinteikkäisiin toimistoihin ja pienempiin alan yrittäjiin. Vuonna 2012 Suomen viisi suurinta viestintätoimistoa myyntikatteella mitattuina olivat Miltton, Pohjoisranta Burson-Marsteller, Hill \& Knowlton 
Finland, Cocomms ja Kreab Gavin Anderson. Kaikilla toimistoilla on kansainvälisiä yhteyksiä.

Hill \& Knowlton on yhdysvaltalainen jo vuonna 1927 perustettu PR- ja viestintätoimistoketju, joka toimii yli 50 maassa ja on toiminut Suomessa 1970-luvulta lähtien. Kreab Gavin Andersson on vuonna 1970 perustettu ruotsalais-yhdysvaltalainen yritys ja toimii 25 maassa, Suomessa vuodesta 1988. Vuonna 1995 perustettu Pohjoisranta liittyi yhdysvaltalaiseen Burson-Marsteller-ketjuun, joka on yksi maailman suurimmista viestintätoimistoketjuista. Vuonna 1990 perustettu Cocomms on kansainvälisen viestintätoimistojen ketjun PROI:n partneri sekä maailmaan suurimpiin viestintätoimistoihin kuuluvan Ketchum Pleonin yhteistyökumppani. Vuonna 2001 Suomessa perustettu Miltton on avannut toimipisteet myös Singaporeen ja Brysseliin.

Viiden suurimman toimiston lisäksi alalla toimii suuri joukko pienempiä yrittäjiä ja paljon myös vain yhden tai kahden hengen konsulttitoimistoja. Viestintätoimistojen kenttä myös elää jatkuvasti: toimistoja syntyy ja kuolee ja ne ketjuttuvat tai fuusioituvat.

Haastattelujen perusteella pyrimme luomaan kokonaiskuvan ammattikunnan palveluista ja niistä keinoista, joilla julkisuuteen ja myös poliittiseen päätöksentekoon pyritään vaikuttamaan. Nimettömät haastattelut tehtiin teemahaastatteluina, jotka litteroitiin ja analysoitiin laadullisella sisällönanalyysillä. Kysyimme, mitä palveluja ammattilaiset tarjoavat ja miten he näkevät viestintäpalvelujen kysynnän ja käytön kehittyneen. Kysyimme myös, kuinka he kokivat yhteiskunnan ja julkisuuden muuttuneen ja miten nämä muutokset heijastuivat viestinnän ammattilaisten työhön. Meitä kiinnostivat myös alan kasvun syyt; halusimme pohtia, millaisiin yhteiskunnallisiin ja media-alan muutoksiin alan kasvu liittyy.

Haastattelujen avulla kuvaamme ja tulkitsemme julkisuuden hallintaa nimenomaan alan ammattilaisten näkökulmasta. Ymmärrämme haastatteluja ammattikunnan omana eetoksena, jossa he kertovat, mikä heidän merkityksensä on ja millaista on hyvä julkisuuden hallinta heidän näkökulmastaan (vrt. Kantola 2013a). Pidimme tätä näkökulmaa arvokkaana, koska on kiinnostavaa, miten viestinnän ammattilaiset työnsä mieltävät ja sitä markkinoivat. Samalla tulkitsemme alan kasvua suhteessa yhteiskunnan muutoksiin.

Organisaatioiden viestinnän ja PR-toiminnan tutkimus (esim. Heath 2010; L'Etang 2010) käsittelee samoja teemoja, joista konsultit puhuvat ja peilaamme suomalaisten konsulttien näkemyksiä organisaatioiden viestinnän tutkimukseen. Omassa tulkinnassamme tarkastelemme konsulttien toimintaa kuitenkin erityisesti konsultoinnin yhteiskunnallisessa kontekstissa. Haastatteluissa nousi esiin selvästi, että ammattilaiset näkevät yhteiskunnan muutoksia ja hahmottavat alansa nousun suhteessa niihin.

Haastatteluilla tutkimusaineistona on myös rajoituksia. Konsultit ovat ammattilaisia, jotka paketoivat palvelunsa myytävään muotoon ja levittävät niitä tehokkaasti (Clark 1995; Greatbatch \& Clark 2005). Myös haastattelut ovat osa oman työn markkinointia. Konsulttien ammattitaidon ytimessä on kyky esittää itsensä osaavana ja 
pätevänä. Konsultit esittävät ratkaisuja ongelmiin ja perustelevat, miksi heidän palvelunsa ovat tärkeitä ja myös eettisesti kestäviä. Kertomatta voivat jäädä oman työn kannalta ongelmalliset puolet tai vaikeudet. Tulkitsemmekin haastatteluja kriittisestä näkökulmasta siten, että ne ovat myös osa palvelujen markkinointia. Kun haastateltava esimerkiksi vakuuttaa, että asiakkaan kannalta parasta on pitkä ja vakiintunut suhde viestintätoimistoon, tuomme esiin myös näkökulman, että pitkä suhde on tuottava vaihtoehto myös toimistoille itselleen.

Konsulttien käsitys julkisuuden hallinnasta ei myöskään kerro koko totuutta siitä, miten heidän työnsä lopulta onnistuu ja vaikuttaa. Siksi emme kuvaa sitä, miten julkisuus toimii ja miten sitä hallitaan. Voimme kertoa vain siitä, mitä ammattilaiset yrittävät tehdä työssään. Tämän asian myös alan ammattilaiset itse tiedostavat. Kuvaavaa on, että poikkeuksetta alan ammattilaiset eivät pidä käsitteestä julkisuuden hallinta, koska se antaa kuvan siitä, että heidän ammattitaidollaan julkisuutta voisi yksiselitteisesti hallita. Samaan tapaan puhumme tässä artikkelissa vain siitä, miten julkisuutta pyritään hallitsemaan.

Lopuksi haastatteluja rajoittaa myös se, etteivät konsultit useinkaan puhu suoraan yksityisistä asiakkaistaan, minkä vuoksi konkreettisia esimerkkitapauksia on vähän. Tässä syystä esitämme havaintoja pääasiassa yleisellä tasolla ja jätämme jatkotutkimuksen aiheeksi konkreettiset tapaustutkimukset, jotka olisivat kiinnostava aihe.

\section{Mitä viestinnän ammattilaiset tarjoavat?}

Viestintätoimistot auttavat asiakkaitaan käyttämään hyväkseen julkisuutta ja selviämään sen karikoista. Asiakkaina on ennen muuta yrityksiä, julkishallintoa ja etujärjestöjä. Asiakaskunnassa näkyy selvästi promootiokulttuurin laajentuminen, johon on liittynyt konsulttien lisääntynyt käyttö.

Se on nyt kyllä viimeisen 10 vuoden aikana muuttunut ihan selkeesti. Nähdään se viestinnän merkitys ja se vaikuttavuus ymmärretään ihan [- -] eri tavalla kun aikaisemmin. Se on muuttunut [- -] ammattimaisemmaksi [- -] viestintätoimistoja ehkä pidettiin semmosina tiedotepajoina aikaisemmin.

Yritykset ovat ulkoistaneet monia toimintojaan konsulteille (McKenna 2005) ja julkissektori on seurannut perässä erityisesti 1990-luvulta lähtien (Saint-Martin 2000; Kantola \& Seeck 2010; Kuusela \& Ylönen 2013). Tämä kehitys näkyy myös organisaatioiden viestinnässä. Ajatellaan, että ulkopuolisen konsultin käyttö on joustavaa: konsultit toimivat kustannustehokkaasti ja heiltä saa tarvittaessa erityisosaamista, jota organisaatiosta ei välttämättä löydy. Konsulttitoimistoa on myös helppo vaihtaa, jos työn tulokset eivät vakuuta asiakasta.

Viestintätoimistojen perustehtävä on selvittää, mikä on asiakkaan viesti ja miten sen saa perille mahdollisimman tehokkaasti. Viesti muotoillaan niin, että se palvelee asiakkaan organisaatiota. Sen jälkeen etsitään tärkeimmät kohderyhmät, joille viesti 
suunnataan joko perinteisen tai sosiaalisen median kautta (Zoch \& Molleda 2006; Kent \& Taylor 2003).

Viestinnän ammattilaiset auttavat asiakkaita tiivistämään perussanoman ja etsivät keinoja, joilla se saadaan läpi sekä julkisuudessa että poliittisessa päätöksenteossa. Viestin tiivistäminen on ollut viestinnän ammattilaisten perustaito jo pitkään. Ammattilaiset rakentavat viestejä, jotka ovat hyvin kirjoitettuja, selkeitä ja houkuttelevat mediaa (Spicer 1995; Napoli, Taylor \& Powers 1998). Perusviestin tiivistäminen on korostunut entisestään kun mediaympäristö on monimutkaistunut, fragmentoitunut ja informaatioähkyn tukehduttama. Viesti on hiottava mahdollisimman yksinkertaiseksi ja johdonmukaiseksi, kun edes vakiintuneet instituutiot eivät voi olla varmoja, että niiden sanoma menee läpi (Stanyer 2007, 47). Viestejä yksinkertaistetaan "lines of the day" -tyyppisiksi tarttuviksi sanonnoiksi, jotka yritetään saada läpi koko mediakentässä.

Semmoinen joka pystyy tiivistämään pelkistämään kirkastamaan sen sanoman kolmeen sanaan voi merkitä enemmän kun, koko yliopiston kirjasto. [- -] Se pitäisi saada ymmärretyksi se viesti. Se pitää pystyy esittämään uskottavasti. Ja mielellään pitäisi olla kiinnostava. Ja sitten myöskin hyväksyttävä. [- - ] Jos nämä kaikki toteutuu, niin se menee silloin himaan.

Tiivistäminen ja selkeys on tärkeää myös silloin, kun tavoitteena on vaikuttaa poliittiseen päätöksentekoon. Kuten pitkän linjan konsultti kuvaa:

Oot sä 50-vuotias pörssiyhtiö tai viiden kuukauden ikänen start up -yhtiö, sun pitää pystyy siihen 20 minuuttiin kiteyttään se hienous, miksi sen sijoittajan kannattaisi sijoittaa. Tää sama pätee meidän asiakkaalle, kun hän tapaa jonkun poliittisen päättäjän. 20 minuuttia on keskivertoaika, jos sä mietit vaikka jotain ministeriä tai virkamiestä tai vaikka kansanedustajaakin kaiken sen kiireen keskellä.

Myös viestin kohderyhmät on mietittävä tarkkaan. Konsultit identifioivat tärkeät kohde- ja sidosryhmät ja tekevät viestinnän strategioita, johon voi kuulua sekä julkisuuteen että päättäjiin vaikuttamista. Strategian luomisessa kartoitetaan kohderyhmät ja eri mediat ja foorumit, joilla heidät tavoittaa.

Kyllä se on ihan suunnitelmallista duunia, että ruvetaan miettimään ketä, milloin ja missä me halutaan tavoittaa. Mitkä on semmoisia seminaareja, foorumeita, missä pitää esiintyä? Mitkä on sellaisia lehtiä, mitkä me halutaan: yliöitä, alioita, debatteja? Millä tavalla me twiitataan, viedään esille asioita? Miten saataisiin tämä sosiaalisen median kerrannaisvaikutus hyödynnettyä?

Monien toimistojen ensisijaisena tavoitteena on pitkä asiakassuhde, jossa ne pääsevät suunnittelemaan asiakkailleen viestintästrategioita. Viestinnän suunnittelu halutaan usein osaksi organisaation laajempaa strategiaa niin, ettei se ole muusta 
toiminnasta irrallista (vrt. Grunig 2006). Asiakkaille tarjotaan pitkäjänteistä brändin rakennusta ja maineenhallintaa sekä käytännölliset suunnitelmat niiden toteuttamiseksi. Konsultit korostavat mielellään, että pitkäjänteisyys on menestyksen edellytys, nopeat toimet ja yllättävät kriisit ovat aina vaikeampia hoitaa (vrt. Decker 2012).

Konsultit korostavat myös, että julkisuudessa on hyvä ottaa aloite käsiinsä "proaktiivisesti" ennen muita. Agenda yritetään ottaa haltuun herättämällä keskustelua tietystä aiheesta ennen muita ja niin, että asiat kehystetään julkisuudessa halutulla tavalla.

Kyllä sun pitää kattoo, että sä oot myös ajatusjohtaja, etkä ajatuspuolustaja, eikö niin? Ajatushyökkääjä, etkä ajatuspuolustaja, lätkätermein. Sä olet siellä eturivissä kertomassa ensimmäisenä, seuraat ja teet pelinavauksia. Jolloin siitä tulee uskottavaa, siitä tulee mielenkiintoista.

Asioiden seuraaminen ja kommentoiminen on jälkijunassa kulkemista. Samalla konsultit tietenkin myös puhuvat itselleen töitä - heitä kannattaa hakea apuun jo ennen kuin julkisuus on ajankohtaista. Pitkät asiakassuhteet myös palvelevat toimistoja ja tuovat niille tuloja ja toimintaan vakautta.

Toimistot myyvät myös hyviä suhteita mediaan ja poliittisiin päättäjiin. Konsultit luovat aktiivisesti yhteyksiä journalisteihin (Shin \& Cameron 2003; Yoon's 2005; Howard \& Matthews 2006; Sallot \& Johnson 2006). Monet ammattilaiset pyrkivät rakentamaan pitkäjänteisesti hyvät henkilökohtaiset suhteet journalisteihin. He soittelevat toimituksiin ja tarjoavat juttuaiheita ja -vinkkejä. Toimistoissa on palkattuna myös entisiä journalisteja, jotka ovat arvokkaita, koska he tuntevat entisen ammattikuntansa. He ymmärtävät journalismin toimintatavat ja pystyvät muokkaamaan näkökulman, joka sopii journalismille. Henkilökohtaisten suhteiden avulla myös tapaamiset voivat järjestyä helpommin. Kuten aikaisemmin journalistina työskennellyt konsultti kuvaa:

Mä tunnen henkilökohtaisesti aika ison joukon suomalaista mediapäättäjistä. Joko ne on ollut mun kollegoja tai ne on ollut mun alaisia tai ne on mulle joskus esimiehiäkin [- -]. [- - ] se on tietysti yrityksen käytössä nämä suhteet, pystytään erilaisissa tilanteissa keskustelemaan median kanssa, suoraan silloinkin kun sillä asiakkaalla niitä suhteita ei ole. Että tavallaan mä lainaan tätä verkostoani tietysti sen asiakkaan hyväksi erilaisissa tilanteissa.

Moniin kampanjoihin kuuluu julkisuuden hallinnan lisäksi myös vaikuttajaviestintää ja poliittisten päättäjien lobbaamista, jotka yhdistetään samaan viestintästrategiaan. Monissa toimistoissa on vaikuttajaviestintään erikoistuneita konsultteja, joilla on oma puoluetausta tai muuten hyvät ja monipuoliset yhteydet puoluekenttään. Joissakin toimistoissa on konsultteja, jotka ovat erikoistuneet puoluekentän eri laitamiin ja joilla on hyvät suhteet joko oikeisto- tai vasemmistopuolueisiin. Toimistot myyvät myös hiljaista tietoa päättäjistä. On tärkeä tietää, kenellä on vaikutusval- 
taa puolueen sisällä ja kuka poliittinen päättäjä on kiinnostunut mistäkin politiikan alueesta.

Suhteiden käyttämisellä mediassa tai politiikassa on tietenkin myös rajansa eikä suhteilla saa mitä tahansa. Monet konsultit muistuttavat, että toimittajaa tai päättäjää ei kannata pettää, koska sen voi tehdä vain kerran.

Viestintätoimistot keksivät ja käyttävät erilaisia keinoja, joilla joku asia nostetaan julkisuuteen ja keskustelun kohteeksi. Toimistot pyrkivät usein eri tavoin siihen, että viestit eivät näyttäisi organisaation edunvalvonnalta tai markkinoinnilta. Sanoma yritetään saada läpi journalismina, kansalaiskeskusteluna tai kansalaisliikkeenä eikä niinkään mainoksena. Konsulttikielellä "maksetuista kanavista" on siirrytty "ansaittujen kanavien" hyödyntämiseen. Ammattilaiset laativat valmiita lehtijuttuja tai aineistoja, joita voidaan käyttää uutisten raaka-aineena, tai he rakentavat keskusteluryhmiä verkossa ja pyrkivät saamaan julkisuutta sosiaalisessa mediassa. Sosiaalisesta mediasta on tullut tärkeä toimintakenttä julkisuuteen suuntautuvassa viestinnässä (Eyrich, Padman \& Sweetser 2008) ja se tarjoaa monenlaisia uusia välineitä, joita yritetään hyödyntää luovasti. Esimerkiksi nettisivustoilla (Park \& Reber 2008), blogeilla (Kent 2008) tai twiittaamalla pyritään vahvistamaan mainetta ja luomaan vuoropuhelua asiakkaiden ja sidosryhmien kanssa.

Yksi tapaa nostaa asia esiin journalistisena uutisena on tutkimuksen tai selvityksen tilaaminen. Tutkimustieto on faktaa, josta on helppo tehdä uutisia. Esimerkiksi elokuussa 2013 mediassa uutisoitiin konsulttijätti Boston Consulting Groupin raportista (Tyynysniemi 2013), jossa yritys esitti yhteiskunnallisia parannusehdotuksia Pohjoismaille. BCG:n Yhdysvalloista lennätetty toimitusjohtaja vakuutti, että raportti tehtiin, koska yritys haluaa "auttaa julkisen sektorin ihmisiä ja johtajia, kun heidän pitää saada aikaa isoja muutoksia". Samalla sivun julkisuus valtakunnan ykköslehdessä toimi tehokkaasti kuin mainos - tai tehokkaammin, koska se piti yrityksen raporttia uutisena ja samalla antoi yrityksen kehua saavutuksiaan.

Toinen tavallinen keino on henkilöidä oma viesti. Aluksi mietitään, kuka edustaa yritystä tai etujärjestöä ja voidaan "hyvässä nostaa jalustalle ja huonossa pistää hirttosilmukka kaulaan". Näitä avainhenkilöitä valmennetaan räätälöidyllä koulutuksella. Esimerkiksi toimitusjohtajasta on tullut monessa yrityksessä tärkeä symbolinen keskushahmo, joka luo organisaatiolle yhteistä identiteettiä ja imagoa sekä henkilöstön että asiakkaiden ja osakkeenomistajien suuntaan (Kantola 2009; 2014; Littler 2007; Heinonen 2006). Usein johtajan ensimmäiset kuukaudet ovat tärkeimpiä. Haastattelupyyntöjä tulee uran alussa paljon ja "silloin jos on hyvin valmistautunut niin saa paljon hyviä asioita kyllä läpi”.

Konsultit puhuvat myös ajatusjohtajuuden (thought leadership) luomisesta. Medialle pyritään luomaan puheenaihe tai agenda, jota oman organisaation puhemies nostaa julkisuuteen - ilman häntä asiasta ei oikeastaan voida keskustella. Esimerkiksi tietoturvayritys Stonesoftin palveluksessa ollut Jarno Limnell nousi hahmoksi, joka on aktiivisesti julkisuudessa ja muun muassa pitää blogia Iltalehdessä: 
Pyritään toimialan ajatusjohtajuuteen. Eli Jarno Limnéll on nimenomaan kyberturvallisuuden ajatusjohtaja Suomessa. [- -] Kun tästä asiasta puhutaan, siitä ei voida puhua parhaalla tasolla, ellei Stonesoftin Jarno oo siellä mukana. Et pitäis aina olla, ikään ku hän visioi pitkälle eteenpäin sitä, mihin tää asia on menossa.

Yksi keino julkisuuden valloittamisessa on myös koalitioiden rakentaminen (Davis 2007). Organisaatiot käyttävät viestin viemiseen kolmansia osapuolia, jotka ovat esimerkiksi ministeriöitä, kansalaisjärjestöjä tai kansalaisliikkeitä. Koalitioiden rakentamisesta on monenlaisia strategisia hyötyjä. Asian taakse saadaan enemmän voimaa ja uskottavuutta, eikä se näyttäydy kenenkään erityisenä etuna. Esimerkiksi kuluttajajärjestö voi sopia jonkin yrityksen asian edistämiseen tai jonkin sairauden hoitoon keskittynyt järjestö uuden lääkkeen markkinointiin.

Usein myös käytetään mielipidetiedusteluja, joissa "kansan ääni" saadaan tukemaan omaa asiaa. Suomessa hyvä esimerkki on sairaanhoitajien palkkakiista vuodelta 2007, joka sai valtavaa julkisuutta. Sairaanhoitajien ammattiliitto Tehy käytti apunaan viestintätoimistoa, joka muun muassa teetti palkkavaatimuksia tukeneen mielipidekyselyn siitä, mitä mieltä kansalaiset olivat sairaanhoitajien palkkatasosta.

Sosiaalinen media on tuonut uusia mahdollisuuksia myös liittoumien ja sidosryhmien löytämiseen ja vahvistamiseen (Waters 2009). Sosiaalisessa mediassa voidaan pyrkiä rakentamaan vaikkapa "kansalaisliike" jonkin edistettävän asian tueksi. Kuten kokenut konsultti kuvaa:

Sun pitää saada sinne välillä hyviä mediaulostuloja semmoisia joissa joku kolmas osapuoli tuo esiin. Meidän tehtävä on myöskin kartoittaa sitä että ketkä voisi olla tämmöisiä mahdollisia kolmansia osapuolia. [- -] Parhaimmillaanhan se johtaa siihen et se kolmas osapuoli vie sun viestiä omilla viesteillään ja silloin sää olet tosi vahvalla maaperällä.

Sosiaalisessa mediassa voidaan myös herättää keskustelua, joka ei näytä mainonnalta tai markkinoinnilta. Esimerkiksi bloggaus, nopeasti leviävät huhut tai sissimarkkinointi eivät näytä mainoksilta (Brants \& Voltmer 2011,Voerman 2009) vaan kaverien suosituksilta. Kuten viestinnän ammattilainen kuvaa:

Ei enää tehdäkään telkkaria tai mainoskampanjaa vaan tehdään Youtubeen hemmetin hyvin tehty juttu ja superkäsikirjoitus ja sitten se näyttää kuitenkin vähän siltä että joku nörtti on tehnyt tämmöisen.

Konsultit näkevät itsensä tärkeinä myös organisaatioiden kriiseissä (Coombs \& Holladay 2011). Kriisiviestinnän merkitys on kasvanut, kun julkisuus on muuttunut arvaamattomammaksi, laatujournalismi kamppailee talousvaikeuksissa ja on entistä aggressiivisempaa ja sosiaalinen media lisää julkisuuden avoimuutta ja arvaamattomuutta. (Kantola 2011; Lähde 2010, 43-45.) Kriiseissä konsultit tulevat apuun ja opastavat asiakkaitaan. Usein tavoitteena on ottaa aloite haltuun ja korjata aiheutuneet vauriot maineelle ja organisaation uskottavuudelle. Konsultit eivät esitä, että he voisi- 
vat aina selvittää kriisin, mutta tavoitteena voi olla, että asiakas on pystynyt "kääntymään viestinnän objektista viestinnän subjektiksi" ja kriisin kasvu on estetty reagoimalla siihen nopeasti. Esimerkiksi julkisuudessa yleistyneet anteeksipyynnöt ja pahoittelut ovat yksi tärkeä kriisinhallinnan muoto, jolla organisaation kriisi pyritään pysäyttämään (Coombs \& Holladay 2008; L'Etang 2010; Haigh \& Dardis 2012).

\section{Miksi viestinnän konsultointi kasvaa?}

Miksi viestinnän ammattilaisten määrä näyttää kasvaneen? Tähän on useita syitä. Yleisesti voi sanoa, että konsulttien kasvu kertoo promootiokulttuurin vahvistumisesta ja leviämisestä eri puolille yhteiskuntaa (Wernick 1991; Davis 2013). Yhä useammat organisaatiot miettivät viestintää ja julkista kuvaansa strategisesti (Cottle 2003). Syyt tähän muutokseen kumpuavat useista eri lähteistä, sillä konsulttien asiakasorganisaatioiden tarpeet ja toimintaympäristö sekä sen myötä strategiat vaihtelevat.

Perinteisesti suurin ja rahakkain asiakasryhmä ovat yritykset. Markkinoiden globalisoituminen ja kilpailun kiristyminen, lainsäädännöllisen ympäristön monimutkaistuminen EU:n myötä sekä eettisyyden vaatimukset useilla aloilla lisäävät yritysten tarvetta monitoroida toimintaympäristöään ja olla jatkuvassa vuoropuhelussa viestinnän keinoin (Coombs \& Holladay 2007; Malmelin 2011). Pörssiyritysten esiintyminen julkisuudessa on itsestään selvää pörssin avoimuusvaatimusten ja sijoittajaviestinnän vuoksi. Nykyisessä mediaympäristössä yritykset myös pyrkivät tekemään tuotteitaan tai palvelujaan tunnetuksi muutenkin kuin perinteisin markkinoinnin keinoin ja kanavin (Keller 2009, 141-143). Joillekin yrityssektoreille on myös tärkeää vaikuttaa poliittisiin päätöksentekoprosesseihin nimenomaan julkisuuden kautta:

Joillain firmoilla on, tarvetta nostaa joitain asioita keskustelun aiheeksi vaan sen takia et ne saa, [- - ] poliitikkoja kiinnostumaan niistä asioista.

Monet konsultit nostavat esiin energia-alan sekä lääkeyhtiöt ja terveydenhuoltosektorin tärkeinä asiakkaina. Energiaratkaisut ovat keskeisiä yhteiskunnallisia kysymyksiä ja ne herättävät paljon julkista keskustelua.

Nythän energiapuolella on kaikenmoista, menossa, syöttötariffeja ja päästökauppa on ollut pitkään aika, olikohan siinä tulos taas muutoksia. Ja energialaki uudistetaan [- -] koko ajanhan siellä jotain tapahtuu [- - ] se on kuitenkin näitä strategisimpia hyödykkeitä mitä on. Ja toimijat on isoja, [- - ] joka ikisen ihmisen elämään vaikuttaa ne päätökset, mitä tehdään.

Kun asia nousee esiin julkisuudessa sopivasta näkökulmasta, yritys saa poliittiset päätöksentekijät kiinnostumaan ja myös tapaaminen päättäjien kanssa järjestyy helpommin, kun asiasta on tehty "ajankohtainen". 
Myös yritysten välistä liiketoimintaa harjoittavat business-to-business-yritykset käyttävät julkisuutta saavuttaakseen yritysasiakkaansa ja henkilöstönsä. Medianäkyvyyttä käytetään silloin myös tukemaan yrityksen sisäistä viestintää. Ammattilainen kuvaa:

Kyllähän aina on muistettava, että medianäkyvyys on myöskin sisäistä viestintää. On ihan firmalle eduksi, että firman henkilökunta näkee, että meidän firmasta kirjoitetaan järkevällä, menestyvällä tavalla.

Konsulttien käyttöä selittää myös yritysten entistä kansainvälisempi omistuspohja ja verkostomaisempi toimintatapa. Omistajat, asiakkaat, yhteiskunnalliset sidosryhmät ja myös poliittisen päätöksenteon areenat ovat entistä moninaisempia ja yritysten on pidettävä yllä mainettaan ja sidosryhmäsuhteitaan viestinnällä. Tyypillisiä ovat myös luottamuskriisit ja kohut, jotka johtuvat esimerkiksi ympäristö-, ihmisoikeustai sisäpiiriongelmista. (Tainio, Huolman \& Pulkkinen 2001; Malmelin 2011; Kantola \& Vesa 2013.) Niiden hoitamisessa yritykset turvautuvat usein ulkopuolisiin viestintätoimistoihin. Kuten konsultti kuvaa:

Kaikessa liiketoiminnan toiminnassa läpinäkyvyyden vaatimus on kasvava vaatimus koko ajan. Ei voi ajatella niin, että yritys hoitaa joitakin asioita sektorilla, jossa asioita tehdäänkin vähemmän läpinäkyvästi. Se olis kestämätön tilanne, me tiedetään, että se räjähtää kuin pommi käsiin.

Kansainvälistyneet yritykset ovat myös usein etääntyneet kansallisesta päätöksenteosta ja niiden pääasialliset markkina-alueet sijaitsevat muualla kuin Suomessa. Yritysjohtajat keskittyvät ydintoimintaan - yrityksen arvon lisäämiseen - eivätkä enää pidä yhteyttä poliittiseen päätöksentekoon yhtä tiiviisti. Heidän kalenterinsa täyttyvät kansainvälisestä toiminnasta, ja vaikuttaminen julkisuuteen ja päättäjiin on usein uskottu ammattilaisille. Kuten pitkän linjan konsultit kuvaavat, nuoremman sukupolven ammattijohtajat keskittyvät omaan työhönsä eivätkä hahmota välttämättä kovin hyvin ympäröivää yhteiskuntaa:

Sut kasvatetaan rakentaan bisnestä tai hyvin rahaorientoituneesti tai ehkä insinööri enemmän, jos oikein kategorisoidaan, niin vasemmalta oikeelle laatikoita ja excel-taulukko ja sit siellä on se tuote ja näin. Ei siihen kuulu se, että miten yhteiskunta toimii, miten asiat, mihin sä vaikutat ja mikä se mekanismi on.

Kansainvälistyminen on aiheuttanut myös sen, että Suomeen tulee kansainvälisiä yrityksiä, joille Suomi on tuntematon markkina-alue. Tällaiset yritykset tarvitsevat viestintätoimiston, joka voi auttaa paikallisissa olosuhteissa, tulkita poliittista ilmastoa ja löytää tärkeät kontaktit. 
Kun me puhutaan isoista kansainvälisistä yrityksistä maailmalla: ne miettii Suomea joko investointikohteena tai ne oikeasti haluaisi täältä ostaa jotakin tai rakentaa tänne jotakin tai ylipäätänsä tehdä tässä maassa jotakin, mutta niillä ei ole täällä toimintaa. Ne osaa kyllä löytää pr-toimiston ihan kaivamaan sitä tietoa.

Toisaalta myös kansalliset tuotantoalat ovat hajanaisempia kuin ennen. Esimerkiksi metsäalan yrityksillä on erilaisia intressejä ympäristöstandardien suhteen kun edistyneimmät kannattavat tiukkoja normeja ja peräpään pitäjät eivät. Kun aikaisemmin vaikuttaminen on tapahtunut teollisuuden etujärjestöjen kautta, nyt yksittäisillä yrityksillä voi olla omat intressinsä, joita he haluavat nostaa julkisuuteen ja lobata. Tähän työhön voidaan palkata konsultti.

Oma erityinen asiakasryhmänsä ovat yksityisen ja julkisen rajapinnalla toimivat, joko kokonaan tai osittain valtion omistuksessa olevat yritykset. Niillä on ollut voimakas tarve perustella olemassaolonsa markkinaistumisen ja yksityistämisen paineissa sekä luoda kuvaa organisaatioistaan uudenaikaisina ja dynaamisina. Julkinen sektori koetaan usein vanhakantaisena ja byrokraattisena; ominaisuuksia jotka "tarttuvat" helposti yrityksen imagoon. Samalla valtion omistamissa yrityksissä myös omistus on periaatteessa hajautunut koko kansalle. Kuten konsultti kuvaa:

Siellä on valtio joissakin jopa enemmistö tai kokonaan omistaa sen. Ja sitten valtio olemme me. Ja siinä on kaikki, koko kansa ja sitten poliitikot niin kuin yhdistämässä nivelenä. Ja poliitikot ei ole vastuussa jollekin firmalle vaan [- -] äänestäjilleen. Ja ne ottaa sit monia asioita siinä huomioon. Jos niitä asioit selostetaan sekavasti ja epäselvästi niin silloin se ei viesti mene perille ja silloin tulee harmia.

Valtion omistamat yritykset ovatkin kiinnostava joukko, joka on selvästi vaikuttanut promootiokulttuurin vahvistumiseen yhteiskunnassa. Kansainvälisesti valtionyritysten yksityistämistä pidetään yhtenä pääsyynä sille, että PR-ammattilaisten määrä on kasvanut merkittävästi 1980-luvulta lähtien. Ronald Reaganin ja Margaret Thatcherin yksityistämisohjelmat tehtiin PR-kampanjoilla, ja yksityistetyistä valtionyrityksistä tuli merkittävä asiakaskunta viestintätoimistoille, kun ne yrittivät vallata uusia markkinoita ja viestiä uusille osakkeenomistajilleen (Morris \& Goldsworthy 2013, 14-15). Samanlainen kehitys näyttää tapahtuneen myös Suomessa. Entiset valtionyhtiöt ovat innokkaita konsulttipalvelujen käyttäjiä (Kuusela \& Ylönen 2013).

Myös muualla julkissektorilla valtion ja kuntien organisaatioilla on ollut voimakas halu vastata ajan haasteisiin "ajanmukaisella" viestinnällä. Julkinen sektorin toimijat - ministeriöt, virastot ja laitokset - ovat alkaneet kiinnittää enenevässä määrin huomiota julkiseen viestintäänsä ja imagoonsa. Monet konsultit totesivat, että ne ovat myös yhtä lailla "lobbareita" kuin yritykset tai etu- ja kansalaisjärjestöt: ne rakentavat julkisuuskuvaansa, vaikuttavat sidosryhmiinsä ja kokevat olevansa mainekilpailussa mukana: 
Uusi trendi on se että näitten erilaisten virastojen ja viranomaisten tämmöinen keskinäinen mainekilpailu tulee kiihtymään ja ne myös käyttää viestinnällisiä keinoja ja viestintästrategiaa turvatakseen joko oman reviirinsä tai sitten rahoituksensa tai jonkun muun semmoisen.

Konsultit itse vahvistavat kehitystä markkinoimalla itseään ja kuvaamalla kuinka tärkeää viestintä on. Kuten eräs sanoo, ministeriöllä voi olla ihan samanlaisia lobbaustavoitteita kun Microsoftilla.

Konsulttien lisääntyvää käyttöä voi myös selittää yhteiskunnan muutoksilla, ennen muuta yhteiskunnallisen luottamuksen ohentumisella.Yhteiskunnan rakenteet ovat hajautuneet ja lokeroituneet niin, että luottamuksen rakentamiseen tarvitaan uusia ammattilaisia. Samalla kun monet instituutiot on kyseenalaistettu, median merkitys on kasvanut. Näin eri instituutioiden on tultava entistä enemmän julkisuuteen perustelemaan olemassaoloaan.

Promootioammattilaisten määrä on kasvanut usein juuri silloin, kun yhteiskunnassa tapahtuu muutoksia tai vanha järjestelmä ajautuu kriisiin. (Davis 2007.) Aiemmin Suomi oli selvemmin kerho, jossa päättäjät tunsivat toisensa hyvin sektoreiden yli ja asioista voitiin sopia parlamentaarisissa komiteoissa, toimikunnissa, kolmikannassa ja epävirallisemmissa neuvotteluissa.

Yhteiskuntavaikuttaminen on ollut sitä karvalakkilähetystöjuttua, et siel on varmasti ollut niitä saunaseuroja ja muita akatemioita kaiken näköisiä, joissa on epävirallisesti keskusteltu mut tämmöset, systemaattinen vaikuttajaviestintä niin sitä vasta harjoitellaan

Viestintäkonsultit ovat luottamuksen ammattilaisia, jotka rakentavat hyviä suhteita sekä julkisuudessa että suoralla vaikuttajaviestinnällä. Luottamuksen ohentuminen tarkoittaa myös sitä, että monet instituutiot kuten valtio, puolueet, yritykset, kirkko tai armeija ovat menettäneet suoraa yhteyttään ihmisiin ja niiden paikan ovat usein ottaneet tiedotusvälineet. Kuten mediatutkimuksessa on tapana sanoa, yhteiskunta on medioitunut (Lundby 2009; Kunelius ym. 2009). Mediasta on tullut tärkeä näyttämö, ja saadakseen toiminnalleen ja itselleen uskottavuutta sekä edistääkseen omia tulkintojaan yhteiskunnallisesta kehityksestä monien instituutioiden ja heidän johtajiensa on tultava sinne perustelemaan tekonsa ja oikeuttamaan asemansa (Corner 2003; Pels 2003; Alexander 2011). Samaan aikaan myös julkisuus ja mediat ovat muuttuneet arvaamattomiksi. Suuret laatumediat kamppailevat lukijakunnastaan ja ovat entistä ärhäkämpiä ja erilaiset julkiset kohut heittelevät organisaatioita ja niiden johtajia. (Kantola 2011; Kantola \& Vesa 2013.)

Tarpeesta rakentaa luottamusta uusin keinoin kertoo myös se, että erityisesti 1990-luvulta lähtien monet poliitikot, entiset virkamiehet tai poliitikkojen avustajat ovat siirtyneet viestinnän ammattilaisiksi, lobbareiksi tai konsulteiksi joko suoraan yrityksiin tai viestintäyrityksiin. Tunnetuimpia esimerkkejä ovat kolme entistä pääministeriä, joista Esko Aho palveli Nokiaa, Paavo Lipponen konsultoi Nord Stream -yhtiön 
kaasuputkihanketta ja Matti Vanhanen edustaa Perheyritysten Liittoa. Ministereistä esimerkiksi Suvi-Anne Siimes ja Jyri Häkämies ovat siirtyneet elinkeinoelämän edunvalvojiksi. Suuryhtiöt ovat rekrytoineet myös huippuvirkamiehiä. Ulkoministeriön Veli Sundbäck siirtyi Nokiaan, valtiovarainministeriön Anne Brunila on työskennellyt Metsäteollisuus ry:ssä ja Fortumilla ja vaikuttaa nykyisin neljän suuren suomalaisen pörssiyhtiön, Sanoman, Stora Enson, Sammon ja Koneen hallituksissa. Myös monet toimittajat ovat siirtyneet viestintäalan konsulteiksi.

Viestintätoimistot ovat myös itse haistaneet markkinaraon: monet ovat aktivoituneet ja etsivät uusia, entistä näkyvämpiä toimintatapoja, jotka lisäävät niiden tunnettuutta. Suomeen on rantautunut kansainvälisiä viestintätoimistojen ketjuja, jotka levittävät uusia käytäntöjä. Promootiokulttuurille onkin tyypillistä, että konseptit ja käytännöt monistetaan ja levitetään kansainvälisesti (Aronczyk 2013). Konsulttien toiminnassa tämä näkyy niin, että ympäri maailmaa tunnetut konsultit myyvät itseään olemalla monipuolisesti julkisuudessa. Usein he muokkaavat vanhoja oppeja ja lanseeraavat uusia vallankumouksellisia käsitteitä ja konsepteja, joita on helppo paketoida tuotteiksi (Kantola \& Seeck 2010; Kantola 2013b). Suomessa näkyvä nousija on ollut esimerkiksi 199o-luvulla aloittanut Pohjoisranta, joka on lanseerannut organisaatioille erityisesti maineenhallintaa (Heinonen 2006; Aula \& Heinonen 2011). Viime aikoina julkisuuteen on noussut erityisesti viestintätoimisto Miltton, johon siirtyi näyttävästi kokoomuksen pääministerin erityisavustajana toiminut Jussi Kekkonen ja myöhemmin sdp:n valtiovarainministerin erityisavustajana toiminut Matti Hirvola sekä Suomen Olympiakomitean puheenjohtaja, Veikkauksen ex-toimitusjohtaja Risto Nieminen. Viestintäkonsulttien ja lobbarien julkinen näkyvyys on verrattain uutta Suomessa, ja osa haastateltavista suhtautui siihen karsaasti, koska viestinnän ammattilaiset ovat perinteisesti pysyneet itse poissa julkisuudesta uskottavuussyistä.

\section{Mitä merkitystä konsulteilla?}

Viestintäkonsulttien käytössä on kyse rahan tuomasta vaikutusvallasta, koska konsultointi on kallista. Siksi yritykset ovat selkeästi viestintätoimistojen tärkeimpiä asiakkaita, ja niillä on eniten resursseja käyttää palveluja, erityisesti kalliita vaikuttajaviestinnän palveluita. Energia-, lääke- ja finanssialan suuryritykset mainitaan usein tärkeinä käyttäjinä. Voi olla myös ongelmallista, jos erilaiset valtion virastot, ministeriöt ja laitokset panostavat veronmaksajien rahoilla omaan julkisuuskuvaansa.

$\mathrm{Ne}$, joilla ei ole rahaa, voivat jäädä jalkoihin. Monet konsultit toteavat, ettei heillä ole juurikaan asiakkaina kansalaisjärjestöjä, koska näillä ei ole rahaa. Jonkin verran tehdään pro bono -työtä hyviksi katsottujen asioiden parissa.

Käyttäjien epätasapaino herättää kysymyksen siitä, onko julkinen tila ja poliittinen vaikutusvalta ostettavissa. Yksioikoista vastausta ei ole. Miller ja Dinan (2008, 5) toteavat, että median lähdekäytännöillä on taipumus suosia niitä, joilla on parhaat resurssit ammattimaiseen PR-toimintaan. Tutkimuksen mukaan lisääntynyt PR:n käyttö on auttanut lähinnä hallituksia ja suuryrityksiä, joilla on suuret resurssit käy- 
tettävissään. Toisaalta on esitetty, että PR:n käyttö on mahdollistanut vähäresurssisemmille lähteille kuten Britanniassa kansalaisjärjestöille ja ammattiliitoille sellaisen pääsyn mediaan, jota niillä ei aiemmin ole ollut. (Davis 2004, 27.) Erityisesti internet ja sosiaalinen media kanavina ovat luoneet vähäresurssisemmille toimijoille uudenlaisia mahdollisuuksia viestiä ja tavoittaa suuriakin joukkoja.

On myös silmiinpistävää, että monien viestinnän ammattilaisten toiminta tähtää viestintään, jossa viesti välittyisi muuten kuin maksettuna markkinointina. Usein näiden strategioiden keskeinen kohde on julkisuus ja journalismi (Cottle 2003; Davis 2007, 55-73). Valtamedian journalisteille pyritään syöttämään sisältöjä tai uskottavuutta haetaan ohittamalla heidät nostamalla asioita julkisuuteen sosiaalisen median avulla, josta aihe voi sitten levitä organisaation kehystämänä laajemmin julkiseen keskusteluun. Julkisuuteen yritetään myös nostaa yrityksen tai etujärjestön kannanottojen sijaan tosiasioilta näyttäviä tutkimustuloksia, arvostettuja ajatusjohtajia tai kansanliikkeitä.

Onkin huolestuttavaa, että samaan aikaan kun nämä uudet keinot ja niitä keksivät PR-koneistot ovat vahvistuneet, journalismi on vaikeuksissa (Kantola 2013a). Konsultit tunnistavat myös journalistien lisääntyneen kiireen: toimituksissa ollaan ehkä entistä avoimempia valmiille aineistolle ja aiheille, koska journalistien työtahti on kasvanut.

Lähdekritiikkiin jää vähemmän aikaa (Juntunen 2011) ja verkkoviestintä muuttaa journalismin käytäntöjä ja suhdetta lähteisiin (Mörä 2011). Ammattimaisten PRkoneistojen valta kasvaa, jos journalistit laskevat työtahdin kiristyessä ja uusien vaikutuskeinojen kehittyessä yhä enemmän niiden varaan tiedonsaannissaan (Davis 2002, 173). Samalla rajat maksetun mainonnan ja journalistisen aineksen välillä ovat vaikeammin havaittavia. Journalismissa etsitään uusia ansaintalogiikkoja ja juttuformaatteja, joissa maksetun ja toimitetun aineiston raja voi hämärtyä. Sanomalehdissä kehitellään verkkomainoksia, joissa yritykset voivat esitellä itseään monipuolisesti.

Viestinnän ammattilaisten käyttöä tuskin voi rajoittaa, mutta sitä voisi tehdä läpinäkyvämmäksi. Viestinnän ammattilaisten toiminta on Suomessa toistaiseksi poissa julkisuudesta ja erityisesti lobbaamisessa heidän roolinsa on pimennossa. Käynnissä onkin keskustelu siitä, pitäisikö luoda rekisteri lobbaajista EU:n mallin mukaan ja pitäisikö politiikasta yksityiselle sektorille siirtyville luoda karenssiajat.

Viestintätoimistot itse ovat tietoisia keskustelusta ja mielipiteet jakautuvat. Useimmat eivät pidä julkisuutta tarpeellisena tai suomalaiseen kulttuuriin sopivana asiana, toiset taas kannattavat avoimuutta, joka lisäisi luottamusta toimialaan. Edunvalvonnan eettiseen sääntelyyn on syntynyt myös niin sanottu Edunvalvontafoorumi. Sen avulla alalla pitkään toimineet ammattilaiset pyrkivät luomaan yhteisiä pelisääntöjä - ehkä myös välttääkseen lainsäätäjän tiukemman sääntelyn ja pitääkseen huolta alan maineesta. Asiaan liittyy läheisesti myös kysymys politiikan pyöröovista. Onko oikein, että poliitikko voi siirtyä lobbariksi tai journalisti viestinnän ammattilaiseksi ilman karenssiaikoja?

Kaiken kaikkiaan organisaatioiden viestinnän ja PR-ammattilaisten ammattikunnan kasvu ja keinovalikoiman monipuolistuminen kertoo siitä, että alan toimintaan on hyvä kiinnittää entistä enemmän huomiota ja sitä kannattaa tutkia. Kiinnostavia 
aiheita ovat erilaiset kampanjat ja niiden toteutus. Kuinka erilaiset intressitahot vievät ja saavat sanomansa lävitse? Millaisia uusia keinoja tässä kamppailussa käytetään ja mitä merkitystä niillä on? Viestinnän ammattilaisten lisääntynyt käyttö on tärkeä osa julkisuuden muutosta, jossa painopiste siirtyy suurten medioiden käytöstä aktiiviseen ja älykkääseen julkiseen toimintaan, jossa sisältöjä tuotetaan räätälöidysti ja kekseliäästi. Tämä toiminta ansaitsee myös entistä enemmän kriittistä tutkimusta, jossa sen uusia käytäntöjä ja vaikutuksia pohditaan ja tehdään entistä läpinäkyvämmiksi.

\section{Kirjallisuus}

Ahonen, Katariina \& Hanska, Jari (2010). Lobbarin tähtäimessä: Millaisena kansanedustajat näkevät lobbauksen? Pro gradu -työ, viestinnän ja poliittisen historian laitos, valtiotieteellinen tiedekunta, Helsingin yliopisto.

Alexander, Jeffrey (2011). Performance and Power. Cambridge: Polity.

Allern, Sigurd (2011). PR, Politics and Democracy. Central European Journal of Communication, 4: 1, 123-137.

Andersson, Allison (1993). Source-Media Relations: The Production of the Environmental Agenda. Teoksessa: Hansen, Anders (toim.). The Mass Media and Environmental Issues. Leicester University Press, 51-68.

Aronczyk, Melissa (2013). The Transnational Promotional Class and the Circulation of Value(s). Teoksessa: McAllister Matthew P. \& West, Emily (toim.) The Routledge Companion to Advertising and Promotional Culture. New York: Routledge, 159-174.

Aula, Pekka \& Heinonen, Jouni (2011). M2: Maineen uusi aalto. Helsinki: Talentum.

Brants, Kees \& Voltmer, Katrin (2011). Introduction: Mediatization and De-centralization of Political Communication. Teoksessa: Brants, Kees \& Voltmer, Katrin (toim.). Political Communication in Postmodern Democracy. Challenging the Primary of Politics. Houndmills: Palgrave, 1-18.

Clark, Timothy (1995). Managing Consultants: Consultancy as the Management of Impressions. Buckingham: Open University Press.

Coombs, Timothy W. \& Holladay, Sherry J. (2007). It's Not Just PR: Public Relations in Society. Oxford: Blackwell Publishing.

Coombs, Timothy \& Holladay, Sherry (2008). Comparing Apology to Equivalent Crisis Response Strategies: Clarifying Apology's Role and Value in Crisis Communication. Public Relations Review 34: 3, 252-257.

Coombs, Timothy \& Holladay, Sherry (toim.) (2011). The Handbook of Crisis Communication. Chichester: John Wiley $Q$ Sons.

Corner, John (2003). Mediated Persona and Political Culture. Teoksessa: Corner, John \& Pels, Dick (toim.). Media and the Restyling of Politics. Lontoo: Sage, 67-84.

Cottle, Simon (toim.) (2003). News, Public Relations and Power. Lontoo: Sage.

Davis, Aeron (2002). Public Relations Democracy. Public Relations, Politics and the Mass Media in Britain. Manchester University Press.

Davis, Aeron (2003). Public Relations and News Sources. Teoksessa: Cottle, Simon (toim.). News, Public Relations and Power. Lontoo: Sage, 27-43.

Davis, Aeron (2007). The Mediation of Power. Lontoo: Routledge.

Davis, Aeron (2013). Promotional Cultures. Cambridge: Polity Press.

Decker, Wayne (2012). A Firm's Image Following Alleged Wrongdoing: Effects of the Firm's Prior Reputation and Response to the Allegation. Corporate Reputation Review 15: 1, 20-34.

Eyrich, Nina; Padman, Monica \& Sweetser, Kaye (2008). PR Practitioners' Use of Social Media Tools and Communication Technology. Public Relations Review 34: 4, 412-414.

Fowler, Roger (1991). Language in the News. Discourse and Ideology in the Press. Lontoo \& New York: Routledge.

Franklin, Bob (1994). Packaging Politics: Political Communication in Britain's Media Democracy. Lontoo: Arnold. 
Greatbatch, David \& Clark, Timothy (2005). Management Speak. Why We Listen to What Management Gurus Tell Us. Lontoo: Routledge.

Grunig, James E. (2006). Furninishig the Edifice: Ongoing Research on Public Relations As a Strategic Management Function. Journal of Public Relations Research 18: 2. Saatavilla: http://dx.doi. org/10.4135/9781446221594 (luettu 2.9.2014)

Gullman, Riitta (2006). Lobbaus verkossa: miten poliittiseen päätöksentekoon pyritään vaikuttamaan verkkosivujen avulla? Pro gradu -työ, viestinnän laitos, valtiotieteellinen tiedekunta, Helsingin yliopisto.

Haigh, Michael \& Dardis, Frank (2012). The Impact of Apology on Organization - Public Relationships and Perceptions of Corporate Social Responsibility. Public Relations Journal 6: 1. Saatavilla: http://www. prsa.org/Intelligence/PRJournal/Documents/2012HaighDardis.pdf (luettu 2.9.2014)

Heath, Robert L. (toim.) (2010). The Sage Handbook of Public Relations. Lontoo: Sage.

Heikkilä, Heikki \& Kunelius, Risto (1998). Access, Dialogue, Deliberation. Experimenting with Three Concepts of Journalism Criticism. Nordicom Review 7: 1, 71-84.

Heinonen, Jouni (2006). Mainejohtaja. Helsinki: SanomaPro.

Herkman, Juha (2011). Politiikka ja mediajulkisuus. Tampere: Vastapaino.

Howard, Carole M. \& Mathews, Wilma K. (2006). On Deadline: Managing Media Relations. Prospect Heights: Waveland .

Hurmerinta, Markku \& Pietilä, A-P (2008). Hallitse mediapeli - muuten media hallitsee sinua. Helsinki: Infor Oy.

Ihlen, Øyvind \& Berntzen, Øystein (2007). When Lobbying Backfires: Balancing Lobby Efforts with Insights from Stakeholder Theory. Journal of Communication Management 11: 3, 235-246.

Jaatinen, Miia (1999). Lobbying Political Issues. A Contingency Model of Effective Lobbying Strategies. Inforviestintä, Helsinki. Saatavilla: http://ethesis.helsinki.fi/julkaisut/val/viest/vk/jaatinen/ (luettu 15.5.2013)

Jaatinen, Miia (2000). Lobbaus osana organisaation yhteiskunta-aktiivisuutta. Teoksessa: Aula, Pekka \& Hakala, Salli (toim.). Kolmet kasvot. Loki-Kirjat, Helsinki.

Jaatinen, Miia (2003). Lobbaus. Yritys yhteiskunnan vaikuttajana. Talentum, Helsinki.

Juntunen, Laura (2011). Leikkaa-liimaa-journalismia? Tutkimus uutismedian lähdekäytännöistä. Viestinnän tutkimuskeskus CRC, Sosiaalitieteiden laitos, Helsingin yliopisto. Viestinnän tutkimusraportteja 4/2011.

Kantola, Anu (2002). Se keskustelu jäi käymättä. Poliittinen eliitti ja talouskriisin julkisuus. Teoksessa: Kivikuru, Ullamaija (toim.). Laman julkisivut. Media, kansa ja eliitit 199o-luvun talouskriisissä. Helsinki: Palmenia, 263-300.

Kantola, Anu (2009). The Rise of Charismatic Authority Styles in Corporate Capitalism. Journal of Power 2: 3 , 423-440.

Kantola, Anu (toim.) (2011). Hetken hallitsijat. Julkinen elämä notkeassa yhteiskunnassa. Helsinki: Gaudeamus.

Kantola, Anu (2013a). From Gardeners to Revolutionaries: The Rise of the Liquid Ethos in Political Journalism. Journalism 14: 5, 606-626.

Kantola, Anu (2013b). Branded Revolutionaries: Circulated Gurus as Management Tools in Soft Capitalism. European Journal of Cultural Studies 17: 3, 258-274.

Kantola, Anu (2014). Mediatization of Power: Corporate CEOs in Flexible Capitalism. Nordicom Review, tulossa.

Kantola, Anu \& Seeck, Hannele (2010). Dissemination of Management into Politics: Michael Porter and the Political uses of Management Consulting. Management Learning 42: 2, 25-47.

Kantola, Anu \& Vesa, Juho (2013). Mediated Scandals as Social Dramas. Transforming the Moral Order in Finland. Acta Sociologica 56: 4, 295-308.

Karvonen, Lauri (2010). The Personalization of Politics. A Study of Parliamentary Democracies. Colchester: ECPR Press.

Keller, Kevin Lane (2009). Building Strong Brands in a Modern Marketing Communications Environment. Journal Of Marketing Communications 15: 2/3, 139-155.

Kent, Michael (2008). Critical Analysis of Blogging in Public Relations. Public Relations Review 34: 1, 32-40.

Kent, Michael \& Taylor, Maureen (2003). Maximizing Media Relations: A Web Site Checklist. Public Relations Quarterly 48: 1, 14-18. 
Kerr, Allan \& Sachdev, Sanjit (1992). Third Among Equals: An Analysis of The 1989 Ambulance Dispute. British Journal of Industrial Relations 30: 1, 127-143.

Korpiola, Lilly (2011). Kriisiviestintä digitaalisessa julkisuudessa. Helsinki: Infor Oy.

Kunelius, Risto; Noppari, Elina \& Reunanen, Esa (2009). Media vallan verkoissa. Tampereen yliopisto, Tiedotusopin laitos A112.

Kuusela, Hanna \& Ylönen, Matti (2013). Konsulttidemokratia. Helsinki: Gaudeamus.

Lees-Marshment, Jennifer (2009). Political Marketing. Principles and Applications. Lontoo: Routledge.

L'Etang, Jacquie (2010). Public Relations. Concepts, Practice and Critique. Lontoo: Sage.

Lilleker, Darren G. \& Lees-Marsment, Jennifer (2005). Political Marketing. A Comparative Perspective. Manchester: Manchester University Press.

Littler, Jo (2007). Celebrity CEOs and the Cultural Economy of Tabloid Intimacy. Teoksessa: Holmes, Sue \& Redmond, Sean (toim.). Stardom and Celebrity: A Reader. Lontoo: Sage, 230-244.

Lundby, Knut (toim.) (2009). Mediatization. Concept, changes, consequences. New York: Peter Lang.

Luostarinen, Heikki (1994). Mielen kersantit: julkisuuden hallinta ja journalistiset vastastrategiat sotilaallisissa konflikteissa. Helsinki: Hanki ja jää.

Lähde, Jussi (2010). Lobbarin tunnustuksia. Teoksessa: Jaskari, Harri; Hyytiäinen, Minna; Lähde, Jussi \& Perttula, Pekka (toim.). Lobbauskirja. Keuruu: kustannusosakeyhtiö Paasilinna, 21-56.

Malmelin, Karoliina (2011). Arvojen markkinat. Oikeuttavat arvomaailmat suomalaisten suuryritysten yritysvastuupuheessa. Väitöskirja. Sosiaalitieteiden laitos, Helsingin yliopisto.

Manning, Paul (1998). Spinning for Labour: Trade Unions and the New Media Environment. Aldershot: Ashgate.

McAllister, Ian (2007). The Personalization of Politics. Teoksessa: Dalton, Russell \& Klingemann, HansDieter (toim.). The Oxford Handbook of Political Behavior. Oxford: Oxford University Press, 571-588.

McAllister, Matthwe \& West, Emily (toim.) (2013). The Routledge Companion to Advertising and Promotional Culture. New York: Routledge.

McKenna, Christopher (2006). The World's Newest Profession. Management Consulting in the Twentieth Century. Cambridge: Cambridge University Press.

Moran, Michael (2008). Representing the Corporate Elite in Britain: Capitalist Solidarity and Capitalist Legitimacy. Teoksessa: Savage, Mike \& Williams, Karel (toim.). Remembering Elites. Blackwell Publishing/The Sociological Review.

Morris, Trevor \& Goldsworthy, Simon (2013). PR Today. The Authoritative Guide to Public Relations. Basingstoke: Palgrave Macmillan.

Mörä, Tuomo (toim.) (2011). Lähdesuoja. Normit, ideaalit ja käytännöt. CRC,Viestinnän tutkimusraportteja $3 / 2011$.

Napoli, Philip; Taylor, Maureen \& Powers, Gerald ( 1998 ). Writing Activities of Public Relations Practitioners: The Relationship between Experience and Writing Tasks. Public Relations Review 25: 3 , 369-380.

Naurin, Daniel (2007). Backstage Behaviour? Lobbyists in Public and Private Settings in Sweden and the European Union. Comparative Politics 39: 2, 209-228.

Park Hyojung \& Reber, Bryan H. (2008). Relationship Building and the Use of Web Sites: How Fortune 500 Corporations use Their Web Sites to Build Relationships. Public Relations Review 34: 4, 409-411.

Pels, Dick (2003). Aesthetic Representation and Political Style: Re-balancing Identity and Difference in Media Democracy. Teoksessa: Corner, John \& Pels, Dick (toim.). Media and the Restyling of Politics. Lontoo: Sage, 41-67.

Saint-Martin, Dennis (2000). Building the New Managerialist State: Consultants and the Politics of Public Sector Reform in Comparative Perspective. Oxford: Oxford University Press.

Sallot, Lynne M. \& Johnson, Elisabeth (2006). To Contact...or Not? Investigating Journalists' Assessments of Public Relations Subsidies and Contact Preferences. Public Relations Review , 32: 1, 83-86.

Scammel, Maggie (1995). Designer Politics: How Elections are Won. Lontoo: MacMillan.

Schlesinger, Philip; Miller, David \& Dinan, William (2001). Open Scotland? Journalists, Spin Doctors and Lobbyists. Edinburgh: Polycon.

Shin, Jae-Hwa \& Cameron, Glen (2003). Informal Relations: A look at Personal Influence in Media Relations. Journal of Communication Management 7: 3, 239-253.

Spicer, Christopher (1995). Organizational Public Relations: A Political Perspective. Mahwah: Lawrence Erlbaum Associates. 
Stanyer, James \& Wring, Dominic (2004). Public Images, Private Lives: An Introduction. Parliamentary Affairs 57: 1, 1-8.

Tainio, Risto; Huolman, Mika \& Pulkkinen, Matti (2001). The Internationalization of Capital Markets: How International Institutional Investors are Restructuring Finnish Companies. Teoksessa: Morgan, Glenn; Kristensen Peer Hull \& Whitley, Richard (toim.). The Multinational Firm. Organizing across Institutional and National Divides. Oxford: OUP, 153-171.

Tyynysniemi, Matti (2013). Konsulttijätti ennustaa Suomelle teollisuustöiden katoa. Helsingin Sanomat, 17.8.2013.

Van Santen, Rosa \& van Zoonen, Lisbet (2009). Stand van de wetenschap: Popularisering en personalisering in politieke communicatie. Tidschrift voor Communicatiewetenschap 37: 2, 155-176.

Voerman, Gerrit (2009). The Politician Strikes Back? Political Blogs as a Means of Becoming Less Dependent on the Media. Teoksessa: Wijfjes, Huub \& Voerman, Gerrit (toim.). Mediatization of Politics in History. Leuven: Peeters, 115-134.

Waters, Richard (2009). Engaging Stakeholders through Social Networking: How Nonprofit Organizations are Using Facebook. Public Relations Review 35: 2, 102-106.

Wernick, Andrew (1991). Promotional Culture: Advertising, Ideology and Symbolic Expression. Lontoo: Sage. Wilson, Des (1984). Pressure, the A to Z of Campaigning in Britain. Lontoo: Heinemann.

Zoch, Lynn, \& Molleda, Juan Carlos ( 2006 ). Building a Theoretical Model of Media Relations Using Framing, Information Subsidies, and Agenda-building. Teoksessa: Botan, Carl H. \& Hazleton, Vincent (toim.). Public Relations Theory II. Mahwah , NJ: Lawrence Erlbaum Associates, 279-310.

Yoon, Young Min ( 2005 ). A Scale for Measuring Media Relations Efforts. Public Relations Review 31: 3 , 434-436. 


\title{
$\boldsymbol{\nabla}$ Artikkeli
}

\section{Historian jokapäiväinen virta sanomalehdessä}

\begin{abstract}
Artikkelissa selvitetään, millainen on historian jokapäiväinen virta sanomalehdessä. Aineistona on vuoden 2008 Helsingin Sanomien 1960-lukua koskevat viittaukset. Kaikkein arkipäiväisintä on satunnainen historian journalistinen esittäminen, joka koostuu usein faktanomaisista viittauksista tapahtuman tai ilmiön taustaan. Tulkitsevammat viittaukset menneisyyteen ovat tietoista historian journalistista esittämistä. Se on aina riippuvaista toimituksellisista valinnoista eikä palaudu ainoastaan journalistisiin käytäntöihin tai ajatukseen ilmiölle ja tapahtumalle olennaisen menneisyyden huomioimisesta. Tietoiset maininnat ovat näkyviä merkityskamppailun paikkoja. Arvioidessaan tapahtumien tai ilmiöiden kestäviä merkityksiä sanomalehti osallistuu julkiseen määrittelyyn yhteiskunnallisesti tärkeästä menneisyydestä. Artikkelin pyrkimyksenä on laajentaa ymmärrystä historian ja journalismin suhteista kaikkein arkisimmassa muodossa. Lopuksi pohditaan, kuinka sanomalehden jokapäiväinen historia nivoo toimittajat osaksi historiaa tulkitsevaa yhteisöä. Näkökulmien, mittakaavan ja selitysten antaminen on journalismin tehtävä, joka heijastuu myös menneisyyden käsittelyyn.
\end{abstract}

AVAINSANAT: journalismi, historia, historian journalistinen esittäminen, historiakulttuuri, jokapäiväinen historia

hmiset saavat suuren osan historiaa koskevasta tiedosta muuten kuin historiantutkimuksena tai -opetuksena, "muita asioita koskevien esitysten sivutuotteina". Historia "tarttuu vaatteisiin" sosiaalisesta ja fyysisestä ympäristöstä - puhutusta, nähdystä, koetusta tai muuten omaksutusta. Myös journalismi on merkittävä elävänä historiakulttuurin toimija. Se osallistuu jokapäiväisin tuottein historian yhteiskunnallisen määrittämisen prosessiin (Kalela 2000), jossa julkisen määrittelyn kohteina ovat yhteiskunnalle tärkeät menneisyyttä ja historiaa koskevat esitykset. Media ei pelkästään selitä päivän tapahtumia, se myös auttaa yleisöä hahmottamaan menneisyyttä ja muokkaa ihmisten historiakäsityksiä.

Useat yhdysvaltalaiset media- ja kulttuurintutkijat pitävät selvänä, että journalismi on keskeinen - jopa keskeisin - tekijä, joka tuo historiatiedon kansalaisten arkeen (ks. Edy 1999; Kitch 1999; Zelizer 2008). Esimerkiksi Zelizerin mukaan journalismi on muistiteknisen rekisteröinnin instituutio (Zelizer 2008, 85). Toimittajista taas on tul- 